\title{
RIBA DALAM INSURANS KONVENSIONAL: SEJAUHMANA KONSEP TAKAFUL BERPERANAN MENANGANINYA?
}

\author{
Asyraf Wajdi Dusuki* \\ Mohammad Mahbubi Ali**
}

\begin{abstract}
Takaful (Islamic insurance) is an alternative concept to conventional insurance, which the Shari'ah prohibits because it contains elements of usury (riba), features of substantial uncertainty (gharar) and gambling (maysir). The present study examines the issue of unequivocally prohibited riba in conventional insurance and how the takaful structure resolves this issue. The study suggests that the takaful model, which is structured based on the concept of mutual assistance, as rooted in the tabarru' principle, can eliminate all riba arising from the exchange features of conventional insurance. The study concludes with a set of actionable policy recommendations.
\end{abstract}

Keywords: Takaful, Insurance, Riba, Tabarru', Tanahud.

\section{Pendahuluan}

Insurans merupakan salah satu instrumen terpenting dalam pengurusan risiko dan perancangan kewangan. Falsafah insurans hakikatnya terbina di atas suatu maksud atau tujuan luhur iaitu mengurus dan menjamin risiko para pencarum daripada sebarang kebarangkalian buruk seperti musibah mahupun kemudaratan yang mungkin melanda pencarum. Walau bagaimanapun, matlamat yang baik sahaja tidak cukup untuk menghalalkan sesuatu perbuatan. Dalam Islam, tujuan yang baik mesti dicapai dengan cara yang baik juga. Dalam kaedah fiqh ada disebutkan bahawa matlamat tidak menghalalkan cara (al-ghayah la tubarriru al-wasilah). Sebab itulah, majoriti ulama mengharamkan instrumen insurans konvensional walaupun mempunyai tujuan yang luhur lantaran mengandungi pelbagai unsur yang diharamkan Syarak seperti riba, maisir (judi) dan gharar (ketidakpastian).

Namun begitu, Islam sebagai agama yang syumul (menyeluruh) dan kamil (sempurna) sentiasa menyediakan jalan keluar terhadap permasalah manusia khususnya dalam pembangunan instrumen alternatif bagi mencapai maksud yang murni seperti mana transaksi insurans konvensional. Penyelesaian 
yang disediakan oleh Islam sebagai alternatif kepada insurans konvensional adalah berasaskan konsep takaful yang dibina di atas prinsip ta 'awun (tolongmenolong), tadhamun (saling menjamin), dan takaful (saling menanggung) yang diterjemahkan dalam konsep tabarru: Melalui prinsip tabarru' ini, pelanggan atau lebih tepat disebut sebagai peserta takaful tidak hanya sekadar mencari perlindungan untuk diri sendiri semata-mata. Sebaliknya para peserta takaful pada dasar dan prinsipnya bersepakat untuk memberikan sumbangan yang akan digunakan untuk saling bantu-membantu antara satu sama lain seandainya manamana peserta dalam skim takaful tersebut tertimpa musibah atau kemudaratan di kemudian hari. Melalui prinsip tabarru' ini juga, isu gharar, maisir dan riba yang menjadi faktor utama menjejaskan keabsahan kontrak insurans konvensional mampu diselesaikan berpandukan prinsip Syariah.

Justeru, makalah ini ditulis bagi membahaskan beberapa persoalan dasar mengenai pengharaman insurans dan bagaimana skim berasaskan prinsip takaful mampu menangani unsur-unsur yang diharamkan sekaligus merealisasikan matlamat Syariah dalam mengharmonikan kehidupan ummah. Bagi tujuan tersebut, perbincangan dan perbahasan dalam makalah ini disusun mengikut beberapa bahagian seperti berikut: Bahagian pertama adalah pendahuluan. Bahagian kedua membincangkan konsep insurans konvensional serta hukumhakam yang berkaitan dengannya. Ini termasuklah menghuraikan secara terperinci pandangan-pandangan ulama berkenaan dengan pengharaman kontrak insurans sebagaimana yang diamalkan dalam sistem kewangan konvensional. Bahagian ketiga pula akan membincangkan secara lebih terperinci mengenai isu riba dan pengharamannya dalam Islam sebelum bahagian keempat memfokuskan secara tuntas mengenai aspek riba dalam insurans yang menjadi salah satu unsur terpenting menjejaskan keabsahan kontrak konvensional tersebut. Seterusnya, bahagian kelima membahaskan konsep takaful sebagai alternatif terhadap konsep insurans yang mengandungi pelbagai unsur haram yang dicela Islam. Bahagian akhir kertas ini memberikan kesimpulan ringkas dan beberapa cadangan untuk lebih memartabatkan konsep takaful di dunia kawangan Islam.

\section{Konsep Insurans Kovensional}

Insurans merupakan kontrak komersil yang termasuk di dalam kategori kontrak pertukaran kewangan ('uqud mu'awadat maliyah). ${ }^{1}$ Pelanggan atau disebut juga sebagai pencarum yang menyertai skim insurans pada hakikatnya membeli satu produk dalam bentuk polisi insurans yang berupa jaminan perlindungan terhadap musibah tertentu sebagaimana ditetapkan di dalam kontrak (akad) daripada penjual polisi iaitu syarikat insurans. Bagi tujuan pembelian polisi ini, pelanggan membayar sejumlah wang atau premium dengan kadar tertentu 
yang merupakan harga bagi produk insurans tersebut. ${ }^{2}$ Dengan kata lain syarikat insurans menjual polisi iaitu jaminan perlindungan kepada pelanggan dengan kadar premium tertentu bagi tempoh tertentu untuk jumlah jaminan tertentu. Semua premium yang dibayar pencarum menjadi milik mutlak syarikat insurans sementara sebarang musibah yang melanda sebagaimana yang ditentukan dalam kontrak akan menjadi tanggung jawab syarikat insurans untuk menjaminnya atau membayar sejumlah pampasan sebagaimana yang dipersetujui dalam kontrak. Di sini jelas, bahawa insurans konvensional merupakan kontrak pertukaran atau jual beli yang dibangunkan di atas prinsip-prinsip pemindahan risiko (risk transfer).

Secara umumnya, produk insurans di pasaran ketika ini terbahagi kepada dua bentuk iaitu insurans hayat atau nyawa dan insurans am. Insurans hayat merupakan kontrak bersifat jangka panjang yang merangkumi polisi-polisi perlindungan terhadap kematian, kecacatan, kecedaraan, pendidikan, kesihatan dan lain-lain. Manakala insurans am terdiri daripada kontrak-kontrak yang secara relatifnya berjangka pendek yang melindungi musibah-musibah yang berkait dengan harta dan bahagiannya seperti kenderaan, motor, rumah dan lain-lain.

Ulama kontemporari tidak mencapai kata sepakat dalam menentukan sama ada insurans konvensional dibenarkan atau tidak oleh Syariah. Secara umumnya, terdapat dua kelompok ulama yang membenarkan dan mengharamkan insurans konvensional. ${ }^{3}$ Kedua-dua pandangan ini akan diperjelaskan lebih lanjut seperti berikut:

\section{Ulama yang Membenarkan Insurans Konvensional}

Antara ulama kontemporari yang mengharuskan muamalah dengan insurans konvensional termasuklah seperti Syeikh Abdurrahman Isa, Syeikh Abdul Khalaf, Dr. Muhammad al-Bahi, Sheikh Mustafa Al-Zarqa, Sheikh Ali al-Khafif, Sheikh Muhammad Abduh dan lain-lain. Pendapat mereka disandarkan kepada beberapa hujah dan dalil sebagaimana berikut: ${ }^{4}$

1. Insurans adalah kontrak moden yang tiada dalil (nas) yang jelas mengenainya. Justeru, sebahagian ulama menganggap insurans diharuskan (mubah) berasaskan kaedah fiqh yang mengatakan bahawa:

Hukum asal setiap perkara adalah harus sehingga ada dalil yang menunjukkan haram. ${ }^{5}$

Ia juga berdasarkan kepada ayat suci al-Quran:

Dan Dia memudahkan untuk (faedah dan kegunaan) kamu, segala yang ada di langit dan yang ada di bumi, (sebagai rahmat pemberian) daripadaNya; sesungguhnya semuanya itu 
mengandungi tanda-tanda (yang membuktikan kemurahan dan kekuasaanNya) bagi kaum yang memikirkannya dengan teliti. ${ }^{6}$

Golongan ulama ini juga menegaskan bahawa kontrak insurans mempunyai maslahah (kepentingan umum) kepada pencarum. Tanpa insurans, keluarga terdekat akan menanggung beban penderitaan kewangan yang besar selepas kematiannya. Selain itu turut dinyatakan bahawa mengambil insurans telah menjadi adat (uruf) kepada masyarakat.

\section{Qiyas Akad Insurans kepada Konsep Muwalah}

Akad muwalah adalah kesepakatan di antara dua pihak di mana satu pihak membayar diyat kepada pihak yang lain di atas perbuatan jenayah yang dilakukannya. Mereka juga bersepakat untuk saling mewarisi. Konsep ini sudah wujud sejak sebelum Islam dan diperakui Islam sebagaimana pendapat Ibn Abbas, Ibn Mas'ud dan Madzhab Hanafi. Qiyas ini berdasarkan kesamaan illah antara insurans dan muwalah iaitu saling tolong menolong. Ulama yang sependapat dalam hal ini antaranya adalah Sheikh Abdullah alShiyam, Ahmad Taha al-Sanusi, dan al-Zarqa.

Namun demikian, penggunaan qiyas ini dianggap lemah oleh ulama yang berbeza pandangan kerana mereka berpandangan 'illah yang diguna pakai adalah tidak sama antara asl (muwalah) dengan furu ' (insurans). Ini disebut sebagai qiyas ma'al fariq. Bagi mereka, 'illah pensyariatan bagi muwalah adalah tolong menolong, sedangkan insurans konvensional merupakan kegiatan komersil yang bukan terbina di atas prinsip tersebut tetapi untuk menghasilkan keuntungan semaksima mungkin.

\section{Qiyas Akad Insurans kepada Akad Mudharabah}

Sebahagian ulama dalam kelompok yang mengiktiraf insurans konvensional turut meng-qiyas-kan insurans konvensional dengan akad mudharabah. Mereka berpendapat bahawa insurans konvensional secara amalannya adalah menyerupai transaksi akad mudharabah. Pendapat ini dipegang oleh Sheikh Abdul Wahhab Khallaf.

Walau bagaimanapun, pengkritik kepada pandangan ini berhujah bahawa qiyas tersebut juga tidak boleh diterima kerana secara amalannya premium yang dibayar oleh pencarum (sebagai $\mathrm{rabb} \mathrm{mal}$ ) berpindah pemilikan kepada syarikat insurans konvensional (sebagai mudharib). Bahkan premium tersebut tidak kembali sama sekali kepada pencarum jika tidak berlakunya sebarang musibah yang dilindungi oleh syarikat insurans. Ini berbeza dengan konsep dan ciri-ciri akad mudharabah, di mana modal yang diserahkan oleh rabb mal kepada mudharib masih menjadi pemilikan rabb mal. Jika tiada 
kerugian di akhir tempoh kematangan kontrak, modal mudharabah tadi mesti dikembalikan kepada rabb mal yang merupakan pemilik mutlak harta tersebut.

\section{Ulama yang Mengharamkan Insurans Konvensional}

Disebalik pandangan segelintir ulama yang mengiktiraf keharusan insurans konvensional, majoriti ulama kontemporari berpendapat bahawa kontrak insurans konvensional tidak menepati prinsip Syariah kerana terdapatnya elemen-elemen yang diharamkan dan boleh menjejaskan keabsahan kontrak tersebut. Pandangan ini didasarkan pada beberapa alasan dan dalil berikut:

1. Insurans konvensional mengandungi unsur gharar yang dilarang. Dalam satu hadith yang diriwayatkan oleh Abu Hurairah diceritakan bahawa Rasulullah S.A.W melarang jual beli yang mengandungi unsur gharar (ketidakpastian).

Rasulullah melarang jual beli gharar. $^{7}$

Al-Jurjani mendefinisikan gharar sebagai sesuatu yang tidak diketahui hasil akhirnya apakah akan terjadi atau tidak. ${ }^{8}$ Sebahagian yang lain mendefinisikan gharar sebagai kontrak di mana hasilnya tidak diketahui atau tersembunyi atau salah satu kemungkinan di mana kejadian yang kerap berlaku adalah yang lebih dikhuatiri. ${ }^{9}$ Dalam insurans konvensional, elemen gharar terjadi kerana subjek akad iaitu polisi perlindungan adalah suatu yang tidak pasti sama ada akan berlaku atau tidak berlaku. Apa yang pelanggan beli adalah semata-mata sebuah polisi bertujuan mendapatkan ketenteraman pemikiran (peace of mind) terhadap suatu musibah yang belum pasti berlaku sedangkan harga telahpun dibayar bagi maksud pembelian polisi tersebut. ${ }^{10}$ Ianya juga tidak pasti berapa jumlah pampasan (claim) atau manfaat yang akan diterima oleh pelanggan sekiranya berlakunya musibah. Perlu ditegaskan di sini, kewujudan gharar dalam akad mu'awadah atau pertukaran jual beli tidak boleh sama sekali dikompromikan kerana ia akan menyebabkan kontrak tersebut menjadi tidak sah dan apa jua hasil pulangan daripadanya menjadi haram untuk diterima.

2. Insurans konvensional juga mengandungi unsur perjudian (qimar) atau maysir yang dilarang oleh Syariah. Allah berfirman:

Hai orang-orang yang beriman, sesungguhnya (meminum) khamar, berjudi, (berkorban untuk) berhala, mengundi nasib dengan panah, adalah termasuk perbuatan syaitan. Maka jauhilah perbuatan-perbuatan itu agar kamu mendapat keberuntungan. ${ }^{11}$ 
Al-Zayla'i mendefinisikan maysir sebagai sebuah aktiviti yang memberikan kebarangkalian yang serupa untuk kedua-dua belah pihak bagi menanggung kerugian. ${ }^{12}$ Dalam maysir, ada pihak yang $100 \%$ untung tetapi di sisi lain ada pihak yang mengalami $100 \%$ kerugian. Dalam insurans konvensional, maysir terjadi kerana jika musibah berlaku, syarikat insurans akan menanggung kerugian untuk membayarkan polisi kepada pencarum. Sebaliknya, jika tiada kemalangan atau kerugian yang berlaku, pencarum pula yang akan menanggung kerugian sejumlah premium telahpun dibayar bagi tujuan pembelian polisi tersebut.

3. Dalam insurans konvensional terdapat cara pengambilan harta manusia dengan cara atau akad yang batil kerana terjadinya gharar dan maysir. Allah berfirman:

Hai orang-orang yang beriman, janganlah kamu saling memakan harta sesamamu dengan jalan yang batil, kecuali dengan jalan perniagaan yang berlaku dengan suka sama-suka di antara kamu. Dan janganlah kamu membunuh dirimu; sesungguhnya Allah adalah Maha Penyayang kepadamu. ${ }^{13}$

Majlis Fatwa Kebangsaan Malaysia pada 1972 telah menganggap bahawa insurans konvensional terutamanya insurans hayat adalah fasid yang mana diharamkan kerana mengandungi elemen gharar, maysir, riba dan aktivitiaktiviti yang tidak patuh Syariah. Sebelum itu, Jawatankuasa tersebut telah mengeluarkan fatwa menyatakan bahawa insurans am iaitu selain daripada insurans hayat adalah harus. ${ }^{14}$ Pada tahun 1985 pula, Islamic Fiqh Academy di Jeddah di bawah naungan Organisation of Islamic Conference (OIC) menyatakan bahawa semua jenis insurans konvensional (hayat dan am) tidak menepati prinsip-prinsip Syariah. ${ }^{15}$

Selain unsur-unsur haram yang disepakati oleh ulama kontemporari yang mengharamkan insurans konvensional, elemen riba juga dijadikan antara alasan terpenting oleh majoriti ulamak yang berpendirian bahawa insurans konvensional adalah haram. Memandangkan isu riba dalam insurans konvensional merupakan fokus utama makalah ini, bahagian berikutnya akan memulakan perbincangan dengan memberikan kefahaman ringkas mengenai riba dalam prinsip muamalah Islam. 


\section{Konsep Riba dalam Islam}

Riba daripada sudut bahasa bermaksud pertambahan atau lebihan. ${ }^{16}$ Secara istilah, ulama Hanbali mendefinisikan riba sebagai tambahan dalam sesuatu yang tertentu, sementara mazhab Hanafi mendefinisikan riba sebagai suatu tambahan atas harta tanpa ada timbal balik (iwadh) dalam pertukaran harta dengan harta. ${ }^{17}$ Disebut juga dalam definisi lain:

Riba ialah suatu tambahan tanpa ada sebarang bentuk imbalan (iwadh) sebagaimana disyaratkan dalam akad jual beli atau akad pinjaman ketika berlakunya pertukaran harta sebagaimana yang ditetapkan dalam piawai Syariah. ${ }^{18}$

Riba diharamkan dalam Islam melalui nas-nas yang jelas dari al-Qur'an, hadith, dan kesepakatan ulama (ijma ). Antara ayat al-Qur'an yang menerangkan tentang pengharaman riba adalah seperti berikut:

Orang-orang yang memakan riba tidak dapat berdiri melainkan seperti berdirinya orang yang kemasukan syaitan lantaran (tekanan) penyakit gila. Keadaan mereka yang demikian itu, adalah disebabkan mereka berkata, sesungguhnya jual beli itu sama dengan riba, padahal Allah telah menghalalkan jual beli dan mengharamkan riba. Orang-orang yang telah sampai kepadanya larangan dari Tuhannya, lalu terus berhenti (daripada mengambil riba), maka baginya apa yang telah diambilnya dahulu (sebelum datang larangan); dan urusannya (terserah) kepada Allah. Orang yang mengulangi (mengambil riba), maka orang itu adalah penghuni-penghuni neraka; mereka kekal di dalamnya. ${ }^{19}$

Selain itu, terdapat beberapa hadith Rasulullah saw. yang menjelaskan pengharaman riba, antara lain adalah hadith yang diriwayatkan oleh Jabir ra:

Rasulullah saw. melaknat pemakan riba, pemberi riba, penulis yang mencatat transaksi riba dan saksi-saksi kedua-duanya. Rasulullah mengatakan mereka semua adalah sama. ${ }^{20}$

Ayat al-Qur'an dan hadis Rasulullah saw. di atas jelas menegaskan pengharaman riba. Dalam Islam, riba merupakan elemen yang mesti dihapuskan kerana ia akan menjadikan manusia malas berusaha dan mencari kesenangan daripada hasil usaha orang lain dan boleh menimbulkan penindasan serta boleh menyebabkan putusnya amalan bantu-membantu sesama manusia. Sebab itulah juga Islam mengisytiharkan perang kepada orang-orang yang memakan harta riba sebagaimana dalam ayat al-Quran yang disebutkan di atas. 
Majoriti ulama membahagikan riba kepada dua, iaitu riba fadhl dan riba nasi'ah. Sementara mengikut Mazhab Syafie, riba terbahagi kepada tiga jenis iaitu riba al-fadl, riba nasi'ah dan riba al-yad. Secara lebih komprehensif riba dalam Islam terbagi menjadi dua bagian besar: ${ }^{21}$

1. Riba ad-duyun (riba dalam hutang piutang): Ia merupakan kadar faedah tambahan (riba) yang disebabkan oleh pemberian hutang atau kerana berlakunya penangguhan dalam pembayaran. Riba dalam bentuk ini terbahagi kepada dua jenis iaitu:

a. Riba al-qard: kadar atau sebarang manfaat tambahan yang disyaratkan kepada nilai pokok pinjaman. Keadaan ini dibuat pada awal kontrak pinjaman, yang disyaratkan oleh pemberi pinjaman kepada peminjam.

b. Riba al-jahiliyyah: kadar atau sebarang manfaat tambahan yang melebihi nilai pokok pinjaman (principal) disebabkan kegagalan peminjam membayar balik pinjaman dalam tempoh masa yang dipersetujui. Pemberi pinjaman mengenakan denda ke atas peminjam kerana permintaan untuk melambatkan pembayaran balik hutang atau disebabkan kegagalan penghutang membayar hutang dalam tempoh yang ditetapkan.

2. Riba al-buyu' (riba dalam pertukaran yang melibatkan barangan ribawi, yaitu mata wang dan makanan): apabila berlakunya ketidaksamaan berat, nilai atau kuantiti daripada pertukaran dua barangan ribawi yang sama jenis atau berlakunya penangguhan dalam pertukaran yang melibatkan barangan ribawi sama ada daripada jenis yang sama ataupun berlainan. Riba al-buyu' ini juga terbahagi kepada dua bentuk:

a. Riba al-nasi'ah: berlakunya penangguhan dalam pertukaran atau perdagangan dua barangan ribawi yang berlainan jenis tapi dengan illah yang sama. Sebagai contoh 5 geram emas dijual pada harga RM2,000 secara tangguh.

Dalam Islam, wang adalah salah satu daripada enam komoditi ribawi. Oleh kerana itu, pertukaran wang mestilah mengikut syarat tertentu dalam pertukaran emas dan perak iaitu: ${ }^{22}$ (i) jika pertukaran melibatkan matawang yang sama maka nilai pertukaran juga mesti yang sama (mathalan bi mathalin), (ii) jika pertukaran melibatkan matawang berlainan, maka nilai pertukaran tidak semestinya sama, namun penyerahan mesti dilakukan secara lani (spot) tanpa sebarang penangguhan (yadan bi yadin). Ini berdasarkan 
hadith yang diriwayatkan oleh 'Ubadah ibn al-Samit r.a. bahawa Rasulullah saw. bersabda:

Emas dengan emas, perak dengan perak, gandum dengan gandum, barli dengan barli, kurma dengan kurma, garam dengan garam, (ditukarkan) sesama sendiri, pada kadar yang sama, secara tunai, apabila barangan berkenaan yang berbeza ditukar, maka jual belilah sesuka hatimu selama mana ia adalah pertukaran tunai. ${ }^{23}$

b. Riba al-fadhl: merupakan pertukaran atau perdagangan komoditi ribawi yang sama jenis dengan timbangan yang berbeza (sekiranya dijual mengikut berat) atupun kuantiti (sekiranya dijual mengikut kuantiti). Sebagai controh pertukaran 5 gram emas (gred 916) dengan 6 gram emas (gred 750). Ini adalah riba kerana kedua-dua barangan tersebut mestilah ditukar dengan kuantiti yang sama. Kualiti dan gred emas tidak mempengaruhi hukum.

\section{Riba dalam Insurans Konvensional}

Sebagaimana telah disebutkan di atas, majoriti ulama kontemporari turut menegaskan bahawa pengharaman insurans konvensional adalah disebabkan oleh unsur riba yang terdapat di dalamnya. ${ }^{24}$ Riba wujud dalam insurans konvensional dalam tiga keadaan:

1. Riba al-fadhl wujud apabila berlakunya pertukaran wang dengan wang yang lazimnya tidak dalam kadar yang sama. Ini kerana pemegang polisi insurans (policyholder) membayar wang kepada syarikat dalam bentuk premium untuk mendapat manfaat atau pampasan (claim) juga dalam bentuk wang sekiranya berlakunya musibah seperti kemalangan. Ia adalah riba kerana jumlah wang yang dibayar oleh pemegang insurans kepada syarikat insurans tidak sama dengan jumlah wang pampasan yang diterima. Contohnya bagi insurans hayat, nilai wang pampasan jika berlakunya musibah biasanya jauh lebih besar daripada premium yang dibayar oleh pembeli insurans khususnya pada peringkat awal tempoh polisi. Begitu juga, rata-rata premium insurans kenderaan hanyalah sebahagian kecil daripada nilai kereta yang dilindungi. Katakan bagi sebuah kereta baru yang nilai dilindungi berjumlah RM30,000, premium yang perlu dibayar hanyalah sekitar RM1,000. ${ }^{25}$

2. Riba al-nasi'ah juga merupakan bentuk riba kedua yang wujud dalam transaksi insurans konvensional. Ini kerana tempoh masa pertukaran antara wang yang dibayar sebagai premium, sama ada secara berkala 
ataupun sekaligus semasa kontrak ditandatangani dengan penyerahan wang pampasan (jika berlaku musibah) tidak berlaku secara lani (spot). ${ }^{26}$ Sebarang penangguhan pertukaran wang dengan wang termasuk dalam kategori riba al-nasi'ah yang diharamkan.

3. Elemen riba juga wujud dalam transaksi insurans konvensional lantaran operasi pelaburannya yang seringkali melibatkan urusniaga berasaskan riba seperti pelaburan dalam instrumen-instrumen perbankan konvensional, bon, dan sebagainya.

\section{Konsep Takaful Menghilangkan Riba}

Setelah memahami isu-isu mendasar yang menjadi teras kepada pengharaman instrumen insurans konvensional, bahagian ini akan memperincikan bagaimana Islam menyediakan cara alternatif bagi mencapai maksud yang sama dengan konsep insurans iaitu melindungi masyarakat daripada musibah. Secara khususnya konsep alternatif ini dikenali hari ini dengan istilah takaful atau ta'min ta 'awuni.

Takaful berasal daripada perkataan dasar kafala yang bererti jaminan atau tanggung rugi. Secara teknikal, takaful adalah satu bentuk insurans di mana sekumpulan peserta bersetuju untuk menyumbang sejumlah wang (donation/ contibution/tabarru) untuk saling membantu antara satu sama lain sekiranya berlaku sebarang musibah, bencana atau masalah samaada dalam bentuk kerugian harta benda ataupun kematian, kecederaan dan kecacatan kekal pada masa hadapan. Organisasi Perakaunan dan Pengauditan bagi Institusi Kewangan Islam (AAOIFI) dalam Piawaian Syariah yang diterbitkannya menakrifkan takaful sebagai:

Satu sistem di mana para peserta menderma sebahagian atau semua sumbangan mereka untuk digunakan bagi tujuan membayar tuntutan ganti rugi yang dialami oleh sesetengah peserta. Peranan syarikat adalah dihadkan kepada menguruskan operasi insurans dan melabur caruman insurans. ${ }^{27}$

Konsep takaful ini pada hakikatnya berdasarkan kepada prinsip ta 'awun (saling tolong menolong), tadhamun (tanggungjawab bersama), dan perlindungan serta jaminan bersama yang termasuk dalam kategori kontrak-kontrak yang bersifat tabarru؛ Ini didasarkan pada firman Allah:

Bantulah antara satu sama lain dalam kebaikan dan takwa, tetapi tidak membantu satu sama lain dalam melakukan dosa dan pencerobohan. ${ }^{28}$

Ia juga disokong oleh hadith yang menyatakan: 
Barangsiapa yang meringankan satu kesulitan daripada kesulitankesulitan dunia seorang mukmin, maka Allah akan ringankan untuknya satu kesulitan daripada kesulitan-kesulitan Hari Kiamat. Barangsiapa yang memudahkan seorang yang mengalami kesulitan, maka Allah akan beri kemudahan untuknya di dunia dan di akhirat. Barangsiapa yang menutup aib seorang muslim maka Allah akan tutup (aibnya) di dunia dan di akhirat. Allah akan sentiasa membantu hamba-Nya selagi mana dia saling membantu antara satu sama lain. ${ }^{29}$

\section{Prinsip Tabarru'Mendasari Takaful}

Konsep takaful diperkenalkan untuk menghilangkan unsur-unsur yang tidak dapat diterima dalam insurans konvensional, seperti riba, dengan menggantikan kontrak asas insurans daripada kontrak pertukaran (mи'awadhat) kepada konsep kebajikan (tabarru).

Secara bahasa, tabarru' berasal daripada akar kata tabarra'a yang bererti sumbangan, derma, hadiah, sedekah tanpa mengharapkan sebarang pulangan sebagai pengganti. ${ }^{30}$ Tabarru' adalah sumbangan sukarela yang diberikan oleh seseorang semasa hayatnya kepada orang lain, tanpa mengharapkan apa-apa balasan, yang membawa kepada pemindahan pemilikan sesuatu subjek daripada penderma kepada penerima. ${ }^{31}$ Majlis Penasihat Syariah (MPS) Bank Negara Malaysia mendefinisikan tabarru' sebagai sebuah akad berasaskan derma dan kemurahan hati untuk melepaskan pemilikan dana sumbangan sebagai hadiah demi memenuhi kewajiban saling membantu di mana dana dimaksudkan akan digunakan untuk membayar pampasan. ${ }^{32}$

Dengan demikian, elemen riba dalam insurans konvensional boleh dihapuskan melalui operasi takaful kerana alasan berikut:

a) Akad yang melandasi takaful adalah tabarru' bukan mu'awadhat. Dalam akad tabarru', isu riba tidak terjadi kerana riba hanya berlaku pada akad mu'awadhat. Al-Maidani mengatakan:

Riba dalam definisi syara' adalah kelebihan yang tiada padanya timbal balik atau pulangan yang selari dengan piawaian syara, yang disyaratkan pada salah satu antara dua pelaku akad dalam akad mu'awadhat. ${ }^{33}$

Dalam kaedah fiqh juga dinyatakan:

Dimaafkan dalam akad tabarru' apa yang tidak dimaafkan dalam akad mu'awadhah. ${ }^{34}$

Syariah menetapkan tidak berlakunya riba dalam akad tabarru' kerana 
tujuan akad bukan untuk memaksima keuntungan dan tujuan komersil. Dalam takaful, tujuan peserta bukan untuk mendapatkan keuntungan melalui pertukaran wang atau meminjamkan wang, tetapi untuk membantu antara satu sama lain dengan cara memberikan sebahagian dananya sebagai derma atau sumbangan. Sebaliknya, dalam akad mu'awadhat, tujuan akad adalah untuk pertukaran dan keuntungan. Dalam insurans konvensional, pencarum dan syarikat melakukan pertukaran atau jual beli wang dengan wang. Wang dalam bentuk premium dibayar oleh pelanggan atau pencarum untuk mendapatkan polisi insurans konvensional yang juga dalam bentuk wang, yang akan dibayar oleh syarikat insurans jika berlakunya musibah.

b) Dalam operasi takaful semua dana-dana yang dilaburkan hanya dalam bentuk aktiviti-aktiviti yang mematuhi prinsip Syariah sahaja. Syarikat takaful sentiasa dipantau agar tidak terjebak dengan aktiviti pelaburan dana-dana peserta dalam portfolio-portfolio pelaburan yang diharam dan dilarang Syarak seperti pelaburan berasaskan riba, perjudian, arak dan sebagainya.

\section{Kontrak-kontrak dalam Operasi Takaful}

Sebagaimana yang telah dibincangkan di atas, elemen terpenting yang membezakan insurans konvensional dengan takaful ialah kontrak yang mendasari aktiviti keduanya. Disebabkan insurans merupakan kontrak yang berasaskan pertukaran atau jual beli, isu-isu riba, gharar dan maisir yang merupakan unsur terpenting bagi menentukan keabshaan transaksi perlu diberikan perhatian sepenuhnya. Manakala, kontrak tabarru' yang mendasari operasi takaful menghilangkan elemen-elemen haram kerana tujuan akad bukan lagi berasaskan pertukaran yang bermotifkan keuntungan tetapi lebih berupa kebajikan bagi setiap peserta membantu antara satu sama lain.

Walau bagaimanapun, dalam aplikasi semasa, pelbagai produk-produk takaful diperkenalkan bagi memenuhi pelbagai tuntutan peserta selain daripada perlindungan risiko dan musibah. Ada sesetengah produk yang menggabungkan pelbagai bentuk manfaat lain termasuklah simpanan dan pelaburan. Justeru permeteraian kontrak-kontrak mengikut objektif tertentu dan pengasingan danadana yang berkaitan amat mustahak bagi mengelakkan sebarang isu-isu Syariah yang boleh menjejaskan keabsahan transaksi.

Selain dari itu, produk-produk takaful di pasaran amat terkait dengan pelbagai kontrak yang digunakan khususnya dalam menjustifikasikan hubungan diantara syarikat takaful dengan para peserta skim takaful tersebut. Ini bermakna terdapat dua peringkat penentuan kontrak iaitu: Pertama, kontrak yang mendasari 
hubungan dikalangan peserta skim takaful; Kedua, kontrak yang mendasari hubungan di antara syarikat takaful dengan peserta.

\section{- Kontrak yang Mendasari Hubungan Sesama Peserta}

Kontrak yang mendasari hubungan sesama peserta dalam takaful adalah kontrak tabarru : Ini bermakna setiap peserta yang menyertai skim takaful bersetuju untuk menghibahkan atau menyumbang sejumlah wang bagi tujuan membantu antara satu sama lain jika ada dikalangan mereka yang ditimpa musibah tertentu sebagaimana yang disepakati dalam kontrak.

Dalam konteks ini, sesetengah ulama berpandangan bahawa kontrak tabarru adalah bersifat umum yang boleh dicerakinkan lagi kepada dua bentuk iaitu aliltizam bi al-tabarru'dan al-tanaahud.

(a) Al-Iltizam bi al-Tabarru'

Al-Iltizam bi al-tabarru' ialah satu komitmen untuk melakukan tabarru' atau menyumbang yang boleh digunakan untuk menjustifikasikan hubungan antara peserta sesama mereka atau peserta dengan dana yang disumbangkan. Prinsip ini di sokong oleh AAOIFI, yang secara dasarnya mendefinisikan kontrak yang mendasari hubungan peserta skim takaful dengan dana takaful atau sesama mereka berasaskan kepada al-Iltizam bi al-Tabarru ? $^{35}$

Komitmen untuk menyumbang ini pada dasarnya untuk kepentingan setiap peserta berpandukan semangat untuk saling tolong-menolong dan lindung-melindungi antara satu sama lain daripada musibah dan risiko. Prinsip ini diperkenalkan oleh ulama daripada mazhab Maliki yang menjelaskan bahawa apabila seseorang berhasrat atau membuat komitmen untuk melakukan sesuatu kebaikan tanpa menghubungkannya dengan sesuatu syarat yang lain, dia wajib menunaikannya selagi mana dia tidak mati atau jatuh muflis. ${ }^{36}$

Prinsip ini penting menurut kebanyakan pandangan ulama, kerana tabarru' dianggap tidak lengkap melainkan subjek tabarru' tersebut telah pun berpindah kepada penerima sumbangan walaupun komitmen untuk melakukan tabarru' atau sumbangan telah diberikan. Isu ini dapat dilihat dalam kontrak hibah yang mana qabd atau pegangan terhadap subjek yang dihibahkan adalah satu syarat yang akan menentukan keterikatan (bindingness) akad hibah tersebut. Walau bagaimanapun, bagi ulama dikalangan mazhab Maliki, komitmen untuk melakukan hibah atau sumbangan sudah memadai untuk menjadikan akad hibah tersebut sebagai lazim atau mengikat (binding). ${ }^{37}$ Pandangan ini diasaskan kepada kata-kata 
Saidina Ali dan Ibnu Mas'ud yang menyebutkan bahawa: "Hadiah adalah dibenarkan selagi mana diketahui tidak kira sama ada ia sudah diterima atau tidak." ${ }^{38}$ Ini juga bagi mengelakkan isu yang dibangkitkan Nabi Muhammad saw:

Seseorang yang mengambil balik hadiah atau sumbangannya diumpamakan seperti menjilat ludahnya. ${ }^{39}$

Prinsip iltizam bi tabarru' ini penting dalam aplikasi takaful bagi memastikan komitmen berterusan peserta untuk membuat sumbangan (atau dalam istilah insurans ialah membayar premium). Justeru, sekiranya ada peserta yang lewat atau menangguhkan sumbangannya, syarikat takaful boleh meminta pampasan daripadanya dan dianggap sebagai satu bentuk hutang kepada dana sumbangan peserta sehinggalah dia secara rasmi menarik diri daripada skim atau polisi takaful yang dipersetujui bersama. Ini kerana, adalah menjadi tanggungjawab pencarum untuk melunaskan segala komitmen yang dipersetujui dalam kontrak yang mengikat sebagaimana pandangan AAOIFI yang berasaskan mazhab Maliki. Status keterikatan (binding) kontrak takaful ini amat mustahak bagi syarikat takaful yang bertanggungjawab menguruskan dana-dana tersebut dalam membuat pengiraan terhadap nilai sumbangan berkala bagi setiap peserta dan jumlah pampasan yang akan dipayar pada peserta yang menyertai skim takaful ini.

Selain daripada itu, hubungan dana dengan para penerima pampasan disebut juga sebagai iltizam bi al-ta widh atau komitmen untuk memberi pampasan yang juga satu bentuk iltizam bi al-tabarru: Ia juga dianggap sebagai satu bentuk komitmen bersyarat di mana penyempurnaan komitmen tersebut bergantung kepada keperluan tertentu, terutamanya tuntutan pampasan oleh peserta takaful disebabkan musibah atau kerugian yang melanda. Justeru dalam skim takaful, sumbangan yang diberikan peserta mungkin digunakan secara keseluruhannya atau hanya sebahagian daripadanya yang membolehkan peserta menuntut sebarang lebihan daripada dana pampasan takaful (underwriting surplus). ${ }^{40}$

\section{(b) Tanahud}

Satu lagi bentuk tabarru' yang boleh menjustifikasikan hubungan atau kontrak sesama peserta dalam skim takaful ini ialah tanahud atau alnihd. Al-Nihd atau al-tanahud ialah satu prinsip muamalah Islam yang membawa maksud bertolongan (al- 'aun) atau pemberian atau sumbangan sejumlah dana berasaskan komposisi atau nisbah bilangan peserta (yang terlibat dalam perkongsian dana tersebut). ${ }^{41}$ Ia melibatkan sumbangan 
daripada sejumlah peserta bagi menampung keperluan peserta-peserta dalam kumpulan tersebut. Setiap anggota menyumbangkan makanan dan minuman berasaskan nisbah yang berbeza-beza. Sumbangan tersebut kemudiannya dicampurkan dan dikongsikan secara sama rata sesama anggota. Amalan ini pernah dilakukan pada zaman Rasulullah SAW terutamanya apabila melibatkan perkongsian bekalan makanan oleh para sahabat yang menyertai satu-satu misi peperangan ataupun musafir untuk berdakwah.

Hadis-hadis berikut dapat memberikan gambaran mengenai amalan alnihd atau tanahud ini:

Hadis yang diriwayatkan oleh Jabir bin 'Abdullah:

Rasulullah SAW telah menghantar satu angkatan tentera ke sebelah timur dan melantik Abu 'Ubaidah al-Jarrah sebagai ketua, dan tentera terdiri daripada tiga ratus anggota termasuk saya. Kami berjalan keluar sehingga tiba di satu tempat yang mana bekalan makanan kami kehabisan. Abu 'Ubaidah mengarahkan kami untuk mengumpulkan semua bekalan makanan yang masih ada dan dikumpulkan keseluruhannya. Bekalan makanan milikku berupa tamar. Abu 'Ubaidah mengagihkan kepada kami setiap hari sedikit demi sedikit sehinggalah kehabisan. Setiap kami hanya berkongsi satu tamar sahaja. Aku pun berkata: "Bagaimana satu tamar boleh memberi manfaat?" Jabir kemudiannya menjawab, "Kami mendapat tahu mengenai nilainya, ketika ianya sudah kehabisan." Jabir menambah, "Apabila kami tiba di pantai, kami mendapati sejumlah ikan bagaikan bukit. Tentera memakan daripadanya selama 18 malam. Kemudian Abu 'Ubaidah mengarahkan tulang-tulangnya diikat. Kemudian dia mengarahkan agar unta betina ditunggang dan ia melalui di bawah tulang-belulang (yang membentuk pintu gerbang) tanpa menyentuhnya." ${ }^{\prime 2}$

Di dalam Hadis lain pula:

Daripada Salamah, katanya: Bekalan makanan kaum ini telah berkurangan, dan mereka dalam keadaan berhajat. Mereka menemui Rasulullah SAW untuk menyembelih unta-unta mereka, lalu baginda memberi keizinan. Umar menemui mereka dan mereka memberitahu hal tersebut kepada Umar, lalu Umar bertanya, "Apa yang tinggal untuk kamu selepas 
unta-unta tersebut?" Umar bertemu Nabi SAW, lalu berkata, "Wahai Rasulullah, apa yang tinggal bagi mereka selepas untaunta mereka?". Rasulullah SAW berkata, "Serulah mereka supaya mendatangkan lebihan bekalan makanan mereka". Lalu dihamparkan satu hamparan, dan mereka meletakkan lebihan bekalan makanan di atas hamparan tersebut, lantas baginda SAW berdiri, berdoa, dan memohon keberkatan. Kemudian, baginda memanggil mereka supaya membawa bekas masing-masing, lalu mereka mengambil makanan tersebut hingga habis. Kemudian Rasulullah SAW bersabda, "Aku bersaksi bahawa tiada Tuhan yang sebenarnya kecuali Allah, dan aku adalah Rasulullah."43

Aplikasi tanahud juga seringkali dikaitkan dengan satu amalan yang dilakukan oleh kaum Asy'ari pada zaman Rasulullah SAW:

Daripada Abu Musa, bahawa Rasulullah SAW bersabda "Sesungguhnya kaum Asy'ari apabila mereka kehabisan bekalan ketika peperangan, atau kekurangan makanan untuk keluarga mereka di Madinah, mereka menghimpunkan apa yang ada pada mereka dalam satu karung, kemudian mereka akan membahagibahagikan antara mereka dalam satu bekas secara sama banyak. Mereka daripada aku, dan aku daripada mereka." ${ }^{44}$

Imam Bukhari dan Ibn Hajar al-'Asqalani dalam komentarnya terhadap hadis-hadis ini terutamanya amalan yang dilakukan oleh kaum Asy'ari menjelaskan bahawa al-nihd adalah suatu amalan terpuji dan dibenarkan. ${ }^{45}$ Walaupun jumlah sumbangan dan pengagihan bekalan makanan adalah tidak sama antara satu ahli dengan ahli yang lain, ketidaksamarataan ini dikompromikan lantaran prinsip ta'awun dan tabarru' yang mendasari muamalah sesama mereka. Sekalipun masih ada berbaki daripada jumlah sumbangan yang diagihkan, ia masih boleh dikongsikan sesama ahli.

Justeru prinsip tanahud ini bersesuaian dipraktikkan dalam amalan takaful masa kini terutamanya untuk menjustifikasikan perkongsian daripada lebihan dana risiko (underwriting surplus sharing), ${ }^{46}$ yang diagihkan kepada peserta-peserta setiap hujung tahun sekiranya dana risiko tersebut masih berbaki atau berlebihan.

\section{- Kontrak yang Mendasari Hubungan Diantara Peserta dengan Syarikat Takaful}

Berbanding insurans konvensional yang berasaskan kontrak mu'awadhat atau jual beli yang menatijahkan segala premium yang dibayar peserta atau pelanggan menjadi hak milik mutlak syarikat, skim takaful menilai peranan syarikat takaful 
daripada perspektif yang jauh berbeza. Ini kerana syarikat takaful tidak sesekali menjadi pemilik dana-dana sumbangan peserta takaful. Sebaliknya mereka hanyalah ejen atau pengurus yang membantu mengendalikan skim takaful bagi pihak peserta.

Dalam amalan takaful semasa, hubungan syarikat takaful dengan peserta boleh dijustifikasikan dalam pelbagai bentuk bergantung kepada kontrak yang mendasari setiap model yang diperkenalkan. Secara umumnya, kontrak tersebut adalah Wakalah, Mudharabah ataupun gabungan antara keduanya.

\section{(a) Kontrak Mudharabah}

Mudharabah ialah kontrak perkongsian di mana satu pihak menyediakan modal manakala pihak lain menawarkan kemahiran dan keusahawanan. Keuntungan, jika ada, akan dikongsi berdasarkan nisbah yang telah dipersetujui di awal. Mana-mana kerugian kewangan akan ditanggung sepenuhnya oleh pemberi modal ( $\mathrm{rabb} \mathrm{mal}$ ) sedangkan pengurus dana (mudharib) akan menanggung kerugian usaha dan buruh.

Daripada segi operasi takaful, pemberi modal dikenali sebagai peserta manakala pengurus dana adalah syarikat takaful. Di bawah kontrak ini, pengendali takaful akan menerima sumbangan daripada peserta. Sumbangan itu disifatkan sebagai modal ( $\mathrm{ra}$ 'sul mal) yang akan diurus dan dilaburkan kepada tempat yang mematuhi Syariah. Kontrak ini menyatakan bahawa apa-apa keuntungan daripada pengurusan dana akan dikongsi bersama antara pengendali takaful dan peserta berdasarkan nisbah yang dipersetujui terlebih dahulu. Walau bagaimanapun, sekiranya berlaku kerugian dalam Dana Risiko Peserta (DRP), pengendali takaful selalunya akan memberi pinjaman tanpa faedah ( a ard) yang perlu dibayar balik apabila DRP menjana keuntungan. ${ }^{47}$ Lebihan daripada dana risiko, jika ada, akan diagihkan kepada para peserta kerana ia bukan merupakan sebahagian daripada keuntungan.

Struktur mudharabah seperti ini membolehkan pengendali takaful hanya menikmati perkongsian keuntungan, dan bukan lebihan dana risiko. Lebihan dana risiko dalam model ini perlu dikembalikan kepada semua peserta kerana ia adalah sebahagian daripada modal, dan tidak berupa keuntungan. Syarat ini tidak disukai oleh kebanyakan pengendali takaful. Oleh itu, pengendali takaful membina model mudharabah yang diubahsuai di mana lebihan pengunderaitan ditafsirkan sebagai "keuntungan mudharabah" yang akan dikongsi antara peserta dan pengendali takaful. ${ }^{48}$ 


\section{(b) Kontrak Wakalah}

Wakalah merupakan kontrak perwakilan atau agensi yang mana satu pihak melantik pihak lain sebagai ejen untuk melaksanakan tugas tertentu. Dalam operasi takaful, pihak yang mewakilkan (muwakkil) terdiri daripada peserta manakala ejen (wakil) adalah pengendali atau syarikat takaful. Dengan kata lain, peserta melantik syarikat takaful sebagai ejen untuk menguruskan danadana yang dikumpulkan bagi tujuan bantu-membantu dalam melindungi para peserta daripada kerugian akibat sesuatu musibah. Sebagai imbalan daripada kerja pengurusan yang dilakukan ini, syarikat takaful berhak untuk menerima fi atau upah sebagaimana yang disepakati di awal kontrak. Dalam model ini juga, syarikat takaful turut dipertanggungjawabkan untuk mengurus dana-dana yang dikumpulkan dengan melaburnya ke dalam skim-skim pelaburan yang mematuhi Syariah. Sebarang keuntungan atau lebihan akan diserahkan kepada para peserta.

Dalam model wakalah ini, lebihan daripada dana risiko (underwritting surplus) tidak dikongsikan dengan syarikat takaful. Oleh sebab itulah, dalam banyak operasi syarikat takaful masa kini, model asal wakalah telah diubah-suai dan ditambah baik. Dalam model wakalah yang diubahsuai, pengendali takaful bukan sahaja dibenarkan untuk mendapatkan bayaran caj atau upah sebagaimana dipersetujui berdasarkan prinsip wakalah di peringkat permulaan kontrak bagi kerja-kerja pengurusan dana risiko yang dilakukannya, tetapi juga dibenarkan mendapatkan sebahagian lebihan daripada dana risiko berdasarkan insentif prestasi (performance incentive).

\section{(c) Model Hibrid}

Model hibrid adalah model takaful yang menggabungkan beberapa kontrak dalam satu produk takaful. Model takaful ini dibangunkan sama ada berasaskan gabungan akad mudharabah dan wakalah atau gabungan antara wakalah dan wakaf. Dalam gabungan mudharabah dan wakalah, kontrak mudharabah digunakan untuk menjustifikasikan peranan pengendali atau syarikat takaful sebagai pengurus dana pelaburan peserta (mudharib), manakala kontrak wakalah digunakan untuk menjustifikasikan peranan pengendali takaful sebagai pengurus dana-dana risiko dan segala aspek yang berkaitan pampasan dan underwriting bagi pihak peserta. Sebagai mudharib, pengendali takaful akan menikmati sebahagian daripada sebarang keuntungan yang terhasil daripada aktiviti pelaburan dana-dana pelaburan berdasarkan suatu nisbah yang telah disepakati di awal kontrak. Di samping itu juga syarikat takaful selaku pengurus dana-dana risiko (underwriter) dan sebarang operasi takaful yang berkaitan pampasan 
terhadap musibah dan sebagainya, berhak untuk menerima upah atau fi wakalah yang tetap sebagaimana yang telah dipersetujui di awal kontrak. ${ }^{49}$

Satu lagi model hibrid ialah gabungan kontrak wakalah dan wakaf. Struktur ini diperkenalkan oleh Sheikh Taqi Uthmani dan banyak diaplikasikan di Pakistan. Idea umum model ini adalah untuk membolehkan mana-mana individu untuk membantu satu sama lain sekiranya berlaku musibah atau malapetaka dengan menggunakan dana wakaf. Melalui model ini, pemegang saham bagi syarikat takaful menyumbangkan dana bagi menubuhkan dana berasaskan prinsip wakaf. Pada masa yang sama, para peserta juga menyumbang sejumlah wang yang akan dimasukkan ke dalam dana wakaf tersebut. Ini bermakna, dana wakaf terdiri daripada dua sumber utama iaitu daripada dana pemegang saham dan dana para peserta takaful. Dana-dana ini kemudiannya dilabur dalam aktiviti perniagaan yang patuh Syariah. Jika mana-mana peserta ditimpa musibah, keuntungan yang dijana daripada dana wakaf boleh digunakan untuk membantu setiap peserta. $^{50}$

Syarikat pengendali takaful dalam model ini juga berfungsi sebagai ejen (wakil) bagi pihak para pemegang saham dan peserta untuk mentadbir dana-dana wakaf tersebut. Ini termasuk kerja-kerja pengurusan risiko dan pembayaran tuntutan daripada peserta. Pada masa yang sama, syarikat takaful juga bertindak sebagai ejen pelaburan untuk membantu melabur dana dalam aktiviti yang patuh Syariah. Bagi kerja-kerja ini syarikat takaful boleh dibayar upah berasaskan kadar tertentu daripada sebahagian sumbangan peserta dan juga upah prestasi (performance fee) sebagaimana yang telah ditetapkan sejak daripada awal pemeteraian kontrak. ${ }^{51}$ Rajah 1 di bawah mengilustrasikan kontrak yang mendasari hubungan antara peserta dengan syarikat takaful.

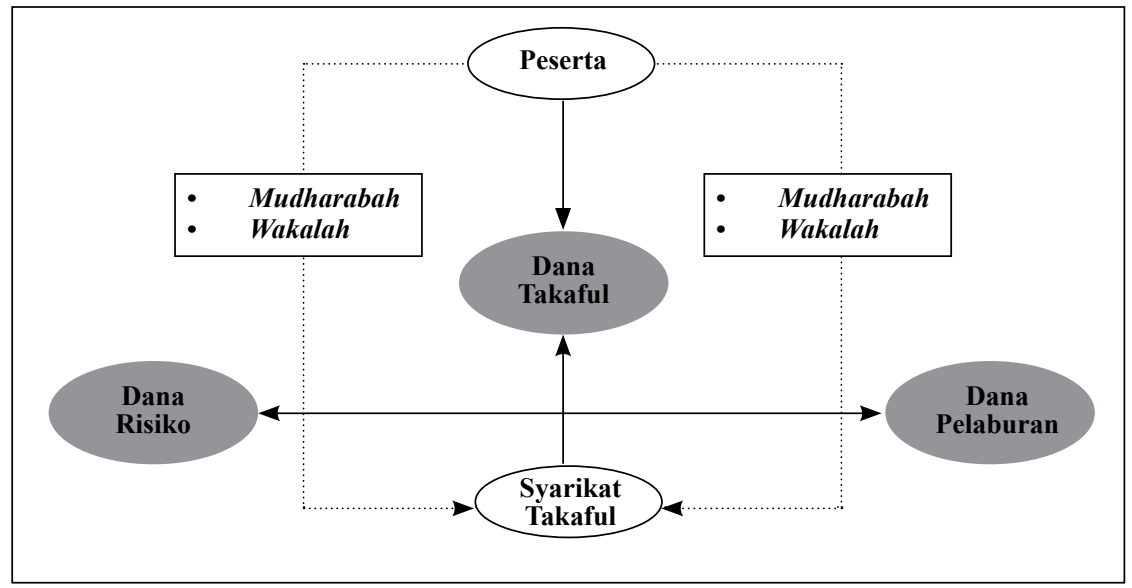

Rajah 1: Kontrak antara Peserta dengan syarikat Takaful. 


\section{Kesimpulan dan Cadangan}

Kertas ini telah membincangkan secara ringkas mengenai isu-isu penting yang mendasari pengharaman insurans konvensional. Secara khususnya penekanan telah diberikan terhadap aspek riba yang menjadi salah satu unsur terpenting yang menjejaskan keabsahan kontrak insurans yang digunapakai dalam sistem kewangan konvensional ketika ini.

Walaupun matlamat atau objektif yang digariskan dalam amalan insurans konvensional boleh dianggap sebagai mulia lantaran fokusnya terhadap pengurusan risiko dan kewangan para pelanggan bagi berhadapan dengan sebarang kebarangkalian musibah dan kemudaratan masa depan, ia tidak memadai untuk menghukumkan keharusan instrumen yang digunapakai daripada perspektif Islam. Ini kerana prinsip Syarak jelas menggariskan bahawa matlamat yang baik mesti disusuli dengan cara dan pendekatan yang betul juga.

Justeru, amalan takaful yang diperkenalkan masa kini dilihat mampu menjadi wahana terbaik bagi menyelesaikan isu-isu riba, gharar dan maisir sebagaimana yang terkandung dalam kontrak insurans konvensional. Secara khususnya, prinsip tabarru' seperti iltizam bi al-tabarru' dan tanahud yang pernah diguna pakai satu ketika pada zaman Nabi Muhammad saw dan sahabat-sahabatnya mampu menyelesaikan isu riba, gharar dan maisir yang diharamkan. Dalam aplikasi moden masa kini, prinsip ini telah digabung-jalinkan bersama kontrakkontrak komersil lain yang dibenarkan Syarak termasuk kontrak wakalah dan mudharabah yang mampu meningkatkan produk-produk kewangan Islam semasa sekaligus memperkasakan lagi sistem kewangan Islam.

Untuk lebih memartabatkan industri takaful, makalah ini mencadangkan beberapa perkara sebagaimana berikut:

1. Perlunya peranan aktif semua pihak berkuasa dalam mendukung perkembangan pasaran industri takaful. Ini kerana pasaran takaful hanya mampu menyumbang $1.1 \%$ daripada total aset kewangan Islam.

2. Perlunya kempen yang berterusan tentang pentingnya umat Islam menyertai skim takaful untuk menyelematkan mereka daripada terbabit dalam pengharaman riba dalam insurans konvensional.

3. Pihak syarikat takaful juga perlu terus-menerus menambah baik produk, operasi dan perkhidmatannya melalui produk-produk yang inovatif, perkhidmatan yang cekap dan pantas, serta harga dan ciri yang kompetitif. 


\section{Notes}

* Asyraf Wajdi Dusuki adalah bekas Timbalan Menteri di Jabatan Perdana Menteri dan Bekas Ketua Penyelidik di Akademi Penyelidikan Antarabangsa Dalam Kewangan Islam (ISRA).

* Mohammad Mahbubi Ali ialah Felo Penyelidik di Institut Kajian Tinggi Islam Antarbangsa (IAIS) Malaysia. Beliau boleh dihubungi melalui email mahbubi@, iais.org.my.

1. Zaharuddin Abd Rahman, Money, You \& Islam: Views on Contemporary Financial \& Islamic Banking Issues (Selangor: True Wealth, 2008), 45.

2. Jamal Hakim, 'Uqud at-Takmin (Beirut: Dar al-Ma'arif, 1965), 1/33.

3. 4. Naseer Yassin \&Jamil Ramly, Takaful: A Study Guide (Kuala Lumpur: IBFIM, 2011), 81-3.

5. Sila rujuk Ali Muhyiddin Al-Qurrah Daghi, At-Ta'min al-Islami Dirasah Fiqhiyyah Ta'shiliyah (Beirut: Dar al-Bashair al-Islamiyah, 2004).

6. Al-Suyuti, Al-Ashbah Wa al-Naza'ir (Beirut: Dar al-Kutub al-Ilmiyyah, 1411H), 60; Ibn Nujaym, Al-Ashbah Wa al-Naza'ir (Beirut: Dar al-Kutub al-Ilmiyyah, 1419H), 56.

7. Qur'an, Surah al-Jathiyah:13.

8. Abu Dawud, Sunan Abi Dawud (Beirut: Al-Maktabah al-‘Ashriyah, t.t), $3 / 254$.

9. Al-Jurjani, Kitab Al-Ta'rifat lil Jurjani (Beirut: Dar Kutub Ilmiyah, 1983), 161.

10. Ali Muhyiddin Al-Qurrah Daghi, At-Ta'min Al-Islami Dirasah Fiqhiyyah Ta'shiliyah (Beirut: Dar Bashair Islamiyah, 2004), 164.

11. Engku Rabiah Adawiyah Engku Ali, A Mini Guide to Takaful (Islamic Insurance) (Kuala Lumpur: CERT, 2010), 21-4.

12. Al-Maidah: 90.

13. Al-Zayla'i, Tabyin al-Haqa 'iq, Sharh Kanz al-Daqa 'iq (Cairo: Al-Mathba 'ah alKubra al-Amiriyyah, 1313H), 6/228.

14. An-Nisa': 29.

15. Diekstrak daripada Minit Mesyuarat Persidangan Jawatankuasa Fatwa Kali Pertama, pada 1-2 Oktober 1970, di Masjid Negara, Kuala Lumpur.

16. Yassin \& Ramly, Takaful: A Study Guide, 84.

17. Ibn Manzur, Lisan al- 'Arab (Beirut: Dar Sadir, (1994), 14/304-05.

18. Wahbah az-Zuhaili, Al-Fiqh al-Islami wa Adillatuhu (Damascus: Dar Fikr, 2004), 5/3698.

19. Ahmad Muhammad Saad, Fiqh al-Mu'amalat, (Jordan: Dar al-Kitab, 2011), $1 / 43$.

20. Qur'an, Surah al-Baqarah: 275.

21. Muslim, Shahih Muslim bi Sharh al-Nawawi (Mesir: Mathba'ah al-Mishriyyah wa Maktabuha, 1981), 11/26.

22. Rahman, Money, You \& Islam, 18-20.

23. Ibid, 46.

24. Muslim, Shahih Muslim, 11/14.

25. Wahbah az-Zuhaili, Fiqh al-Islami wa Adillatuhu, 5/3423. 
26. Wan Marhaini Wan Ahmad et. al., 109.

27. Ibid, 108

28. AAOIFI, Accounting, Auditing \& Governance Standards (for Islamic Financial Institutions), (Bahrain: AAOIFI, 2010), 465.

29. Al-Ma'idah (5):02.

30. Muslim, Shahih Muslim (Beirut: Dar Ihya' Turath al-Arabi, t.t), 4/2074.

31. Rujuk Al-Jurjani, Al-Ta'rifat (Beirut: Dar al-Kutub al-'Ilmiyyah, 1983), 1/256; Muhammad Rowas Qal'aji, Mu jam Lughatul Fuqaha' (Beirut: Dar al-Nafais, 1988), 1/120; Ibrahim Musthafa, et.al., Al-Mujam Al-Wasith (Cairo: Dar alDakwah, t.t), 1/50.

32. Nusaibah Parid, "Insurable Interest in Takaful Pracitices: An Analysis", ISRA Research Paper, no. 03/2009, 13.

33. Bank Negara Malaysia, Resolusi Syariah dalam Kewangan Islam (Kuala Lumpur: BNM, second edition, 2010), 62.

34. Ahmad Al-Kurdi, Al-Ta'min al-Islami wat Ta'min al-Taqlidi Hal Hunaka Furuqun? Kertas kerja dibentangkan pada halaqah mengenai " 'Uqud al-Ta'min al-Islami", 12-14, Januari 2002, Jeddah.

35. Ahmad bin Hammad, 'Uqud al-Ta'min Haqiqatuha wa Hukmuha (Madinah: AlJami'ah al-Islamiyah bil Madinah al-Munawwarah, t.t.), 96.

36. AAOIFI, al-Ma'ayir al-Shar'iyyah (Manama: AAOIFI, 2015), 687.

37. Al Hattab, Tahrir al-Kalam fi Masa 'il Al Iltizam (Beirut: Dar Al Gharb Al Islami, 1984), 71; Abdul Nasir Tawfiq Al Attar, Nazariyyah Al Itizam fil Shari'ah wal Tasyri'at Al Arabiyyah (Egypt: Matba'ah Al Sa'adah, 1975), 22.

38. Wahbah az-Zuhaili, Fiqh al-Islami wa Adillatuhu, 5/3998-9.

39. AAOIFI, al-Ma'ayir al-Shar'iyyah (Manama: AAOIFI, 2006), 446.

40. Al-Bukhari, Shahih Bukhari, Hadith no. 2621 (Dimasyq: Dar Thuq al-Najah, 1422), 3/164.

41. Abdul Sattar Abu Ghuddah, Buhuth fil Mu'amalat wal Asalib Al Masrifiyyah Al Islamiyyah (Jeddah: Majmu'ah Dallah Al Baraka, 2005), 6/300.

42. Ibn Manzur, Lisan Al 'Arab (Beirut: Dar Shadir, 1414), 6/4555.

43. Hasan Khan, Sahih Bukhari (translated), (Riyadh: Dar Al Salam, 1997), 3/47.

44. Ibid, $3 / 137$.

45. Ibid, $3 / 138$.

46. See Ali MA Al Quradaghi, Al Ta'min Al Islami (Beirut: Dar Al Basha'ir Al Islamiyyah, 2004), 256-7; Ibn Hajar Al 'Asqalani, Fath Al Bari (Cairo: Dar Al Hadith, 1998), 3/144.

47. Ali MA Al Quradaghi, Al Ta'min Al Islami, ..., 257.

48. Asyraf Wajdi Dusuki (ed), Islamic Financial System: Principles and Operation (Kuala Lumpur: ISRA, 2011), 516-7

49. Engku Rabiah Adawiyah Engku Ali, Essential Guide to Takaful (Islamic Insurance) (Kuala Lumpur: CERT Publication, 2008), 46.

50. Lihat, Asyraf Wajdi Dusuki (ed), Islamic Financial System: Principles and Operation (Kuala Lumpur: ISRA, 2011), 521-2.

51. Ibid, 522.

52. Ibid, 523. 